\title{
Community Participation in the Payment of the Rural and Urban Land and Building Tax (Pbb-P2) (A Study in Mekarmukti Village, Cisaga District, Ciamis Regency)
}

\author{
$1^{\text {st }}$ Tina Cahya Mulyatin \\ Department of Goverment Science \\ Program, STISIP Bina Putera Banjar \\ Banjar City 46311, Indonesia \\ tina_cahya_mulyatin@stisipbp.ac.id \\ $4^{\text {th }}$ TeguhAnggoro \\ Department of Goverment Science \\ Program, STISIP Bina Putera Banjar \\ Banjar City 46311, Indonesia
}

\author{
$2^{\text {nd }}$ Anwar Musadad \\ Department Midwifery \\ Faculty Department of Goverment \\ Science Program \\ STISIP Bina Putera Banjar \\ Banjar City 46311, Indonesia \\ $5^{\text {th }}$ Dadan Erdian Kosasih \\ Department of Goverment Science \\ Program, STISIP Bina Putera Banjar \\ Banjar City 46311, Indonesia
}

\author{
$3^{\text {rd }}$ Ririn Yulianti \\ Department of Goverment Science \\ Program, STISIP Bina Putera Banjar \\ Banjar City 46311, Indonesia
}

\begin{abstract}
The study is aimed at determining and analyzing the community participation in paying the Rural and Urban Land and Building Tax in Mekarmukti, Cisaga District, Ciamis Regency. To achieve the objective, the study employed qualitative method in which the sample was drawn using purposive sampling technique. The data were collected through observation and interviews. The results showed that the level of community participation in paying the Rural and Urban Land and Building Tax (PBB-P2) reached an average of $80 \%$ per year. Viewed from the leadership aspect, the Head of Mekarmukti village has made an attempt to increase the community participation by issuing a Decree of the Village Head concerning the Formation of the Rural and Urban Land and Building Tax Team (PBB-P2). Meanwhile, in terms of communication aspect, what has been done was carrying out socialization to the local community, providing good service and giving awards. In regard to the education aspect, it was found that the level of education does not affect community participation in paying the Rural and Urban Land and Building Tax (PBB-P2). What needs to be emphasized is the awareness of the taxpayer in fulfilling his obligations as a good citizen.
\end{abstract}

\section{Keywords-Rural, Urban Land, Building Tax, PBB-P2}

\section{INTRODUCTION}

Indonesian citizens basically have the right to prosperity and to carry out their activities related to it. The stability of governmental affairs has to be run smoothly to realize citizens' prosperity and regulate their social matters. Approximately $70 \%$ of Indonesia's state budget is sourced from tax revenues, and the types oftaxes that exist in Indonesia are now diverse. Although the rural and urban property taxes (PBB-P2) are not the most significant contributors to the state revenue from the tax sector, the PBB-P2 taxes has unique characteristics compared to other types of taxes. This difference can be seen from the number of taxpayers in this type of tax more than other types of taxes. The number of taxpayers in PBB-P2 includes all Indonesian citizens who own land and buildings in the territory of Indonesia [1]. To do so, the government needs costs from taxes which is especially the present study concerns on the Rural and Urban Areas Property Tax (here in after reffered as RUAPT), the public citizens highly expect that their fares which is retributed to the government can be implemented as well as possible for the country's progress and citizens' welfare. For those who live in the city areas, they pay tax as mentioned increasingly from year to year which remain very burdensome from them. On the other hand, for those who live in the village, they pay the RUAPT cheaper than previous condition. As a fact for this contradictive condition, the government earns RUAPT less than its portion because they are more likely not to pay their taxes. Whereas, the increase of tax income from RUAPT will help the country to be able to prosper the community and regional development can be evenly distributed. Public facilities such as education, roads, electricity, and health and so on can be realized with the tax income.

In relation to the income tax and realization of RUAPT, the fact data point out that most citizens still have low participation to pay the property tax as their annual obligatory affair. As a result, the government 
performance of the repayment target is still low by June. This condition and obstacles can be solved for improving its gaining effectiveness through good participation from citizens' themselves. To engage good participation from community, the Mekarmukti Village Government needs to provide socialization to the society about the importance RUAPT.

The authors have collected the data from mentioned village which is located at Cisaga District in 2015 to 2017 period about the realization of income tax from RUAPT. It was found that the realization of the RUAPT has not been achieved with good and maximum number even the period of payment exceeded the deadline set by the Mekarmukti Village Government in June.

Based on the data from observations, it was found that several problems which indicated such as; lack of citizens or taxpayers understanding and awareness of RUAPT, the existence of multiple property ownerships, the big number of land owners outside the Mekarmukti Village, Cisaga District.

To increase citizens' participation in paying taxes, the village principal's leadership function must be improved [2]. Because, based on the data from previous study revealed that there was an influence of the leadership of the village principal on his/her citizens' awareness in paying RUAPT in the Matsum City in the number of 3 out of $31.47 \%$ [3]. Aside from leadership, ignorance of the citizens regarding the procedures or procedures for paying taxes is the major obstacle to their participation in paying taxes [4]

The present study aims at measuring citizens' participation in Mekarmukti Village, CisagaSubdistrict, Ciamis Regency in paying the RUAPT and finding out problems encountered and efforts implemented.

\section{LITERATURE REVIEW}

Participation can be defined as one's involvement consciously into social interaction in certain situations [5]. With the previous understanding, someone can participate if he or she with or in groups through various processes of sharing with others in terms of values, traditions, feelings, loyalty, and obedience also shared responsibility. Participation is also interpreted as citizens' participation in the process of identifying problems and potential that exists inside the context, selecting and making decision about alternative solutions to deal with problems, implementing efforts to overcome problems, and community involvement in the process of evaluating changes that occur [6] According to Tjokrowinoto, there are several important factors that need to be considered to be able to increase citizens' participation as follows [7]

- Leadership factors, in which leaderships and its quality are important to drive good participation.

- Communication factors, in which ideas, perspectives, policies and new plans will get support if these are known and understood by the citizens.

- Educational factors, in which adequate level of education, individuals / communities will provide the expected participation.
Tax is a citizens' contribution to the state treasury based on the law (which can be forced) by not gaining reciprocal services (non-achievement) which can directly to be used for general expenditure payment [8]. The definition of regional tax hereinafter is referred to tax, is the contribution of the taxpayer to the area owed by individuals or institution with forced characterized based on its decree which indirect reward and it can be used for regional purposes especially the greatest prosperity of the people. [9]

Regional tax is one of the very important PAD sources for the region, because the results of tax collection will later be used for the government administration and regional development in the implementation of regional autonomy.One of the government policies regarding taxes for reforming Law Number 34 Year 2000 became Law Number 28 Year 2009 concerning Regional Taxes and Regional Retribution.[2].

Law number 28 of 2009 states that there are several types of taxes collected by the regency/city. Regency tax types consist of Hotel Tax Restaurant tax, Entertainment Tax, Advertisement tax, Street Lighting tax, Non-metallic and rock mineral taxes, Parking Tax, Groundwater Tax, Swallow's Nest Tax, Land and Rural and Urban Building Tax, and Land and Building Title Transfer Duty. Especially on the division of Land and Building Tax in Urban and Rural Sector or it is more known as PBB [10].

Property tax is such of tax which attach on material and the amount of paid tax is determined by considerable condition such as land and building subject conditions although the taxpayer ( someone who pays the tax) do not influence the amount of paid tax.

\section{METHODS}

\section{A. Research Design}

This research employed qualitative approach with descriptive research design. The qualitative approach emphasizes on process analysis of inductive process thinking which interconnected to the relationship dynamics between observed phenomena and scientific logic use as always. Participants in qualitative research are natural objects or settings so the present research method is often referred to naturalistic method. Natural objects are those as they are not manipulated by the researcher so that the condition or setting for pre, whilst, and post research is relatively unchanged. In qualitative research, researchers become instruments. Therefore, in qualitative research the instruments are people or human instruments. To be able to become an instrument, the researchers empowered, analysed, photographed, and constructed the objects under study to become clearer and more meaningful.

\section{B. Informant Determination Technique.}

The purposive sampling technique was employed to determine informants, which is focused on the technique of sampling from various data sources with certain considerations. This consideration, for example the person who is considered to know best about what we expect, or maybe he or she has rule for collecting the data so that it will be easier for researchers to explore the object / social situation under study [11] In accordance to the previous context, the present study engaged informants as follows; 
- A village principal

- 2 village tax collectors

- 8 tax payers, which researchers designed taxpayers as key informants

\section{Data Collection Technique}

The present study used some techniques to collect the data as follows;

- Literature Study

- Field Study

- Observation

- Interview

- 3. Document collection

\section{Data analysis Technique}

Data analysis is defined as the systematic process on searching and compiling obtained data from interviews, field notes, and documentation through organizing data into several categories, describing into units, synthesizing, classifying into patterns, choosing which ones are important and will be studied, and withdrawing conclusions so that they are easily understood by themselves and others [10]

The steps of data analysis were employed as it is suggested by the Miles and Huberman Models as the following:

\section{Data Reduction}

It means summarizing, choosing the main points, focusing on the important things, and looking for themes and patterns. Thus, the reduced data provide brief and concise capture and of course the authors will be easier in doing further data collection, and look for it if needed.

\section{Data Presentation}

The data was presented through tables, graphs, pie chart, pictograms and others. Through the mentioned presentation, the data is organized and arranged in a relationship pattern, so that it is more easily understood.

\section{Conclusion drawing / Data Verification}

This final step is aims at drawing meaning of the data that has been displayed. Conclusions in qualitative research may be able to answer the problem formulation that was designed from the beginning or not because it has been stated that the problems and problem formulations in qualitative research are still temporary and develop after the research in the field.

\section{RESULT AND DISCUSSION}

The main reference to measure citizens' participation in RUAPT payment in Mekarmukti Village, Cisaga District is referring to the theory suggested by Tjokrowinoto [9], which is influenced by leadership, communication, and education factors.

\section{A. Leadership factor}

The village principal of Mekarmukti has actualized some policies and activities in increasing citizens' participation for RUAPT payment by issuing a village principal decree on tax work team of RUATP formation to village officers as tax collector to improve citizens' performance motivation in participating their tax payments with scheduled time. From this fact, the first dimension has been already fulfilled. In increasing the property tax (RUAPT) performance target in Mekarmukti
Village, active and good participation from the village government is urgently needed for motivating, directing the citizens or taxpayers in involving participation in paying tax on scheduled time.

\section{B. Communication Factor}

There are various implemented activities for realizing ideas, perspectives, policies and plans which have been carried out by the village principal in Mekarmukti Village in increasing tax payment participation as follows:

\section{Taxpayer Information Dissemination}

The socialization of tax (RUAPT) collection process in Mekarmukti Village has been conducted annually before tax notification distribution to taxpayers. This activity is usually organized in accordance with village activity on Islamic study meeting and other societal activities.

\section{Taxpayer Service}

Improved service quality is expected to increase taxpayers' satisfaction so that their obedience in tax paying increase well. To serve taxpayers in RUAPT payment, they can choose their property tax payment through various ways; manual payment to tax collector, appointed tax payment station, and electronic payment.

\section{Reward Provision}

The success of an activity for tax payment cannot be apart from the human resources participation especially tax collectors. Based on the data found, it is indicated that the appreciation or reward provision of staff for tax collectors can improve their performance to motivate citizens' participation in collecting tax from them.

C. Educational Factor

The level of education can relatively affect one's participation in paying RUAPT. The data points out that those who well educated have less participation in paying RUAPT than those who unwell educated. This can be concluded that citizens' education without awareness is not adequate to improve their good participation in tax payment. So, the authors expect that adequate level of education, they commit the expected participation. On the other hand, in collecting the RUAPT payment, the Mekarmukti Village, Cisaga District, Ciamis Regency found several obstacles which hampered the citizens' participation for the good one as follows;

- Lack of tax collection officers' motivation in conducting tax billing. At the time of tax notification distribustion, the collection officers offer to taxpayer for broading out the tax payment manually since taxpayers have not prepared their money. But if the they have not paid yet, the officers are seemly busy to reoffer in collecting to citizens simultaneously since the . Consequently, the data points out that they generally feel difficulty in paying the tax at a bank or electronic payment location, also the farness distance from their residence is also one of the indicated factors to be belated payment.

- The outside domicile of taxpayers. Based on collected research data, landownerd or taxpayers who are difficult to be reached because they no longer live in Mekarmukti Village, Cisaga District, Ciamis Regency and their newest 
address is unclear. They even do not have relatives or family in Mekarmukti Village so that the tax collection officers cannot communicate well in withdrawing the tax payment. Also, taxpayers who are domiciled outside the village also do not understand some procedures for electronic payment through bank and Electronic Payment Place (TPE).

- Double of multiple tax notification ownership. This is often happened since the issued data from Financial Management Agency of Finance Ciamis Regency Regional and technical problems on issuing the tax notification. When the tax object is sold, the buyer should report the tax object to change their ownership data, but the first hand owner often does not change their ownership which affect one object will be recorded with two taxpayers.

- Lack of taxpayers' background understanding in tax notification maintenance from one generation to others. For example, the certain case of one's ownership who passed away who did not revise to his/her heir or new buyer, as a result, the data has not recorded yet, so the taxpayer who has purchased or heir did not reckon well and report the tax object to Financial Management Agency of Finance Ciamis Regency Regionalfor changing the identity of the tax object so that it inhibits the distribution of tax notofication to taxpayers and sometimes taxpayers are difficult to reach by officers because there is no place to live.

Regarding the aforemnetioned conditions in collecting the property tax, the village principal of the Mekarmukti Village, Cisaga District, Ciamis Regency have efforted some solutions as: 1)Tax information dissemination and socialition. This acrivities have been organized to the taxpayers and citizents in collaboration with e various community activities or at other events; 2). Reward provision at smallest level of tax collection officers for their good achievemnet and motivation in collecting the tax payment quickly. 3). Door to door of tax withdrawal which means the taxt collection officers attend the taxpayers indivually by village motorbike; 4). Monitoring and evaluation process from village principal. This matter is important to be done in measuring th progress of tax withdrawing target.

\section{CONCLUSION}

Generally, taxpayers are found less awareness of the urgency for paying Rural and Urban Areas Propoerty Tax (RUAPT). This can be seen that they often forgot to pay it on scheduled time. Furthermore, the target and realization of Rural and Urban Areas Property Tax (RUAPT) in Mekarmukti Village have an uncertain achievement every year. For 2015 the participation rate reached $88 \%$, it shows lest in 2016 which only reached $86.5 \%$. While the tax payment target reached $87 \%$ in 2017 . Thus, citizens' participation or taxpayers in paying Rural and Urban
Areas Propoerty Tax (RUAPT) in its average $80 \%$ per year.

Various obstacles that hinder citizens' participation in increasing payments for Rural and Urban Areas Property Tax (RUAPT) are the lack of active collection or collector staff in billing, taxpayers who are domiciled outside the village, multiple tax notification ownership, tax objects have been sold to other parties. and the lack of awareness or responsibility of taxpayers in the payment of the Rural and Urban Areas Property Tax (RUAPT) will cause delay in tax payment.

\section{REFERENCES}

[1] A. H. H. Ibrahim, A. Kaunar, and I. N. Adrias, "Government Performance On Property Tax Services Of Rural And Urban Areas In Ternate City."

[2] S. Nisa and Y. A. Rahman, "Study of the Collection and Potency of Rural and Urban Land and Building Tax," Effic. Indones. J. Dev. Econ., vol. 2, no. 1, pp. 354-361, 2019.

[3] F. Arianty and T. A. Purwanto, "PERBANDINGAN PENGENAAN PBB SEKTOR PERDESAAN \& PERKOTAAN DI PROVINSI DKI JAKARTA, BEKASI, \& DEPOK BERDASARKAN SPPT PBB TAHUN 2014 \& 2015," J. Vokasi Indones., vol. 3, no. 1, 2016.

[4] S. N. Y. Sari, "Pengaruh Kepemimpinan Kepala Desa Terhadap Partisipasi Masyarakat Dalam Membayar Pajak Bumi Dan Bangunan Di Desa Sukorejo Kecamatan Ngasem," J. Adm. Publik, vol. 5, no. 046, 2018.

[5] F. Oktaliana, "Pengaruh Kepemimpinan Lurah Terhadap Peningkatan Kesadaran Masyarakat dalam Membayar Pajak Bumi dan Bangunan (di Lingkungan 2 Kelurahan Kota Matsum 3 Kecamatan Medan Kota)," 2009.

[6] I. R. Adi, Perencanaan partisipatoris berbasis aset komunitas: dari pemikiran menuju penerapan. FISIP UI Press, 2007.

[7] A. Wazir, "Panduan Penguatan Menejemen Lembaga Swadaya Masyarakat," Jakarta Sekr. Bina Desa dengan dukungan AusAID melalui Indones. HIVIAIDS STD Prev. Care Proj., 1999.

[8] P. E. R. Mardiasno, "Yogyakarta: Penerbit Andi, 2011," 2011.

[9] S. Moch, "Penyelenggaraan Pemerintahan Desa Berbasis Partisipasi Masyarakat," Malang Setara Press (Kelompok Penerbit Intrans), 2014.

[10] Y. Laely and H. Titiek, "PLANNING ANALYSIS OF LAND AND BUILDING TAX OF RURAL AND URBAN SECTORS AFTER BEING LOCALLY TAXED," Russ. J. Agric. SocioEconomic Sci., vol. 73, no. 1, 2018.

[11] S. Sugiono, "Metode Penelitian Kuantitatif, Kualitatif, dan R \& D," Bandung Alf., 2016. 